\title{
Parlar la ciUtat
}

\section{Topología del espacio urbano. Palabras, imágenes y experien- cias que definen la ciudad Abada, Madrid, 2014 390 págs. 20 euros}

$\mathrm{E}^{1}$ s habitants de les ciutats ens trobem sovint amb intervencions urbanístiques que tenen un impacte en les nostres vides quotidianes i que, tanmateix, ens són totalment alienes: ni se'ns ha preguntat ni sabem qui ha estat l'autor de l'ocurrència. Perplexos, no sabem si les decisions pertanyen als polítics $o$ als arquitectes $i$ als urbanistes; en qualsevol dels casos ens trobem impotents davant dels fets consumats: un comentari, una crítica i a patir-ne les conseqüències. No obstant això, podria incrementar-se la comunicació al voltant dels espais que ocupem; més encara, la manera de conformar-los i el mode de viure'ls tenen molt a veure amb aquesta comunicació i amb els llenguatges que emprem per a establir-la.

El llibre que presentem pretén portar a terme una reflexió no dogmàtica sobre les distintes formes en

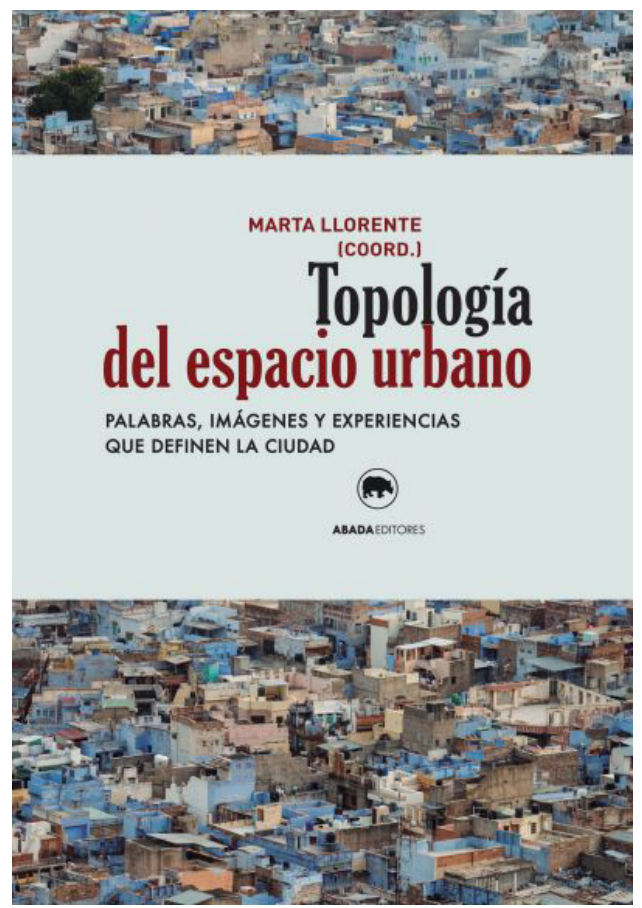

què hom parla de 1'espai; vol mostrar, si més no, una part d'aquests llenguatges.

La tasca s'hi aborda des de diverses perspectives: arquitectura, filosofia, antropologia, història de l'art o periodisme, coherent amb la idea que els llocs on vivim han de ser un afer col·lectiu. 
Compte amb el títol: Topología del espacio urbano. Si passem per alt el subtítol «Palabras, imágenes $y$ experiencias que definen la ciu$d a d »$, podríem pensar que es tracta d'un llibre de geometria. Tanmateix, la paraula topologia l'hem de prendre aquí en sentit etimològic: «dir el 1loc», «parlar sobre l'espai». Els autors, coordinats per Marta Llorente, arquitecta de la Universitat Politècnica de Barcelona, es plantegen una reflexió sobre el llenguatge que emprem, des de les diverses disciplines, des de les diverses experiències, per a parlar de l'espai comú que habitem, per a parlar de la ciutat amb la idea que el llenguatge, més enllà de les perspectives culturals i subjectivitats és l'eina fonamental que permet l'intercanvi d'idees i el debat que ens possibilita donar sentit als espais que habitem, siguen públics o privats.

No és aquest el lloc de fer una síntesi completa d'un llibre de gairebé quatre-centes pàgines ni es pretén fer una crítica de les idees que hi apareixen. Simplement volem presentar un interessant treball multidisciplinari que ens pot obrir algunes finestres $\mathrm{i}$ estimular-nos a participar en el debat sobre els espais que habitem i sobre la seua conformació.
Pau Pedragosa, arquitecte i filòsof en «Decir el lugar», ens parla del «gir espacial», del retorn a l'espai i de la pluralitat dels punts de vista que defineixen l'espai públic.

El gir espacial parteix d'una crítica dels supòsits amb els quals es construeix l'objectivisme. Des d'un punt de vista fenomenològic argumenta que cal recuperar l'experiència viscuda de l'espai que hom ha oblidat en tractar de representar-se objectivament la realitat. Aquesta experiència consisteix a fer l'espai inseparable del temps, de la subjectivitat i del cos. Puix en l'espai es llegeix el temps.

L'espai públic es troba materialitzat urbanament $\mathrm{i}$ arquitectònica $\mathrm{i}$ té una profunditat temporal. Per a comprendre'l cal passar del model científic, que opera a través de l'observació i de l'abstracció a una comprensió realitzada a través del cos $\mathrm{i}$ de la particularització. L'autor postula un retorn a l'espai concret i al subjecte que l'investiga, i proposa la topologia com a mètode. Topologia entesa en el sentit esmentat més amunt. El mètode topològic busca interconnectar més que reduir, trobar interdependències més que simplificar.

Marta Llorente en «El nombre de las ciudades» fa un recompte de les 
primeres paraules que designaren les ciutats, les quals indiquen la consciència ancestral de la singularitat dels centres. Cadascun dels llocs habitats rebia un nom: Babilònia, Tir, Gaza, Damasc. I ja en l'antic Egipte existia una paraula genèrica per a anomenar la ciutat. L'autora repassa les fonts de la literatura grega per a examinar la riquesa de la topologia antiga. Hom constata que el nom genèric de la ciutat, polis, així com els diversos noms que reben els centres habitats apareixen alhora que l'escriptura.

El terme politeia afirma la consciència de la idea mateixa de la ciutat i l'enllaça amb les operacions bèlliques, tècniques i legislatives que originaren la implantació real de les ciutats. Comporta un rebuig de l'ordre material de la ciutat, subvertit en l'àmbit de la literatura llatina (discurs estoic) que dóna prioritat a la cultura material, monumental i escènica, que la història ens obliga a reconèixer com a dominants.

L'autora fa un excursus sobre el significat del terme civitas i la seua evolució històrica. La literatura intervindrà cada vegada més en l'espectacle de la ciutat. Les representacions literàries canviaran el sentit dels viatges i dirigiran els moviments humans.
La literatura moderna i la cartografia són els eixos de la ciutat moderna, representada com és viscuda i habitada com és figurada.

També Marta Llorente, en «La ciudad de la palabra literaria. La ciudad representada: espacio habitado y literatura urbana» vol mostrar alguns aspectes de l'experiència contemporània del medi urbà a través d'exemples literaris, perquè considera que la literatura és la manera més incisiva de representació del medi urbà. La ciutat és un objecte de representació privilegiat. Entre la ciutat real i la representació es crea un circuit de mútues referències, un canal de comunicació entre el fet de viure i el de contemplar, entre la realitat i l'univers de ficció, extrems determinants per a l'experiència d'habitar centres urbans.

La ciutat sembla un collage realitzat a partir de múltiples imatges que es genera en medis i en subjectes, en visitants ocasionals $i$ en els habitants mateixos, en la memòria individual i en l'horitzó dels nostres desitjos collectius.

La constant dissolució contemporània de l'espai urbà, de la seua percepció i de les imatges a través de les quals 1'assimilem, sembla que va 
igualada a la dissolució de les trames narratives tant en la literatura com en el cinema. A mesura que s'enderrocava la trama que donava cohesió als grans relats, la ciutat creixia i desbordava en tots els seus aspectes, la capacitat de captar-la.

La literatura no sols descriu, sinó que fa present, d'una manera o d'una altra, l'espai. L'autora considera que la literatura és un filtre imprescindible dels nostres conceptes i impressions; és una manera d'aprendre a veure l'entorn, el sistema que ajuda a interpretar una realitat tan complexa.

En «El vademécum de la ciudad. La creación de la Barcelona moderna en las guías urbanas», Carmen Rodríguez, historiadora de l'art, constata que no hi ha ciutat immune a les paraules $\mathrm{i}$ a les imatges que la recreen. La ciutat no és només la que recorrem, sofrim o admirem, sinó que també és la que imaginem, fins $i$ tot sense haver-la visitat mai. Amb la industrialització la ciutat esdevé imatge i objecte de consum. La novel·la tingué un paper molt important en el camí que recorren les ciutats i els seus relats. La iconografia urbana esdevé un assumpte per a la major part de les formes d'expressió i comunicació de l'època. Entre aques- tes formes hi ha un lloc per a la guia urbana. La guia és un document que trasllada al lector la imatge més condensada del món, dels paisatges i els territoris dels pobles i de les ciutats. La guia es presenta com l'auxiliar indispensable per a la conversió del viatger en turista modern.

Tanmateix, aquesta estructura narrativa, feta de fragments dispersos, no sempre es correspon amb l'espai físic; sovint expressa la lògica dels interessos que dirigeixen la percepció pública d'una població. Al llarg del segle XIX la iconografia metropolitana colonitza tots els mitjans de comunicació, especialment les guies. Si algun poder van tindre els manuals fou precisament el de suplantar la realitat de l'experiència urbana per la ficció d'uns relats estandarditzats a mida de l'habitant de la ciutat industrial; en aquest sentit les obres tingueren un paper decisiu a l'hora de construir llocs, d'inventar espais, de crear emplaçaments singulars i, en certa mesura, de monumentalitzar el paisatge existent. L'autora analitza la percepció que de Barcelona van donar les guies.

Maurici Pla, en Alison \& Peter Smithson, «Urban Structuring». Un análisis terminológico»s'ocupa dels 
aspectes lingüístics vinculats a la teoria arquitectònica.

Le Corbusier ens adverteix que la teoria arquitectònica moderna ha d'operar una profunda transformació de les lleis tradicionals de la gramàtica. La Charte d'Athènes és una formulació il·lustrada de l'home, de l'arquitectura i de la ciutat d'acord amb aquestes pautes: és un retorn a la raó pura. Alison i Peter Smithson rebutgen visceralment aquest plantejament. Per a ells, l'aprofundiment en la consciència lingüística reemplaça el rigor de qualsevol disciplina científica. I d'aquesta consciència lingüística es desplega una nova raó pràctica. Actualitzen el fonament retòric de tota teoria. En realitat, la teoria arquitectònica podria consistir molt bé en la mera proposta d'un llistat de termes, sense necessitat d'una gramàtica que obligue a construir oracions. La perspectiva d'una teoria arquitectònica desproveïda de verbalització podria projectar una nova llum sobre la naturalesa del fet arquitectònic i obrir així portes a noves modalitats propositives que alguns arquitectes contemporanis han començat ja a assajar.

«Lugares, ocasiones y arquitectura: el discurso antropológico de
Aldo van Eyck», de Ricard Gratacòs, pretén remarcar les contribucions d'Aldo van Eyck al panorama arquitectònic de la segona meitat del segle xx. Per a van Eyck revalorar el rol de la cosa primitiva era necessari en un moment en el qual s'afeblia el dogma racionalista. Veia possible enriquir l'arquitectura i l'urbanisme occidental a través de l'aprenentatge de les maneres d'habitar de les cultures no occidentals. El relativisme científic i cultural representava la fi d'un món on la realitat estava dominada per un punt de vista unidimensional. Van Eyck creu que mentre les cultures antigues i primitives han respost amb un cert èxit a la construcció del seu espai compartit, la societat occidental, tot $\mathrm{i}$ el seu potencial tecnològic a l'abast, només és capaç de construir un espai buit i despersonalitzat. En la ciutat occidental, els ciutadans s'han convertit en mers espectadors de la construcció del seu hàbitat. La distància entre la gent formada en l'àmbit de l'arquitectura i la ciutadania provoca el dilema que presenta la majoria de les noves ciutats europees: han aconseguit que siguen menys i no més habitables.

L'espai i el temps han d'obrir-se a les persones, perquè l'espai sense qui l'habita és un espai buit. El que 
l'arquitecte va voler transmetre als arquitectes: trobar a l'ésser humà a l'interior de l'espai per a poder comprendre el significat del construit. No s'ha de construir l'espai sinó l'interior del mateix, el lloc on hom pot trobar a qui l'habita.

El capítol de Carlos Bitrián «Espacio y memoria. Habitar donde habita el recuerdo de la guerra civil española» tracta sobre la relació entre memòria i espai. Analitza el cas de Corbera d'Ebre, poble destruït durant la darrera guerra civil. Constata que l'espai fou una eina més, i no la de menor importància, per a la transmissió de l'herència totalitària. La gestió de l'espai i de la ciutat es va posar al servei del simbòlic, i al capdavall, de l'oblit.

El pes del passat en el present pot ser excessiu i pot arribar a paralitzar les accions humanes. Tanmateix, la memòria pot ser més que un relat; és també allò que hom experimenta. L'espai és també allò que permet el desenvolupament de la memòria; que permet experimentar en un lloc determinat el que es va ja experimentar una altra vegada. La memòria esdevé en l'espai present la connexió amb altres experiències passades, una manera de comprensió i coneixement.
L'espai ha estat més alterat que conservat, més maltractat que protegit $i$ el component memorial ha tingut menys pes que altres components, com l'econòmic.

Un poble que imposa la destrucció del seu patrimoni i que impedeix així l'experiència lliure de la memòria, en la mesura en la qual impossibilita l'experiència de l'espai en què aquesta pot produir-se, no actua correctament.

M. Teresa Tapada aporta, en «Sobre el concepto de antropología urbana y de antropología del espacio», una reflexió sobre la dispersió terminològica per a comprendre les diverses maneres d'analitzar la ciutat des d'una perspectiva genuïnament antropològica. L'antropologia urbana que apareix a començaments del segle $\mathrm{xx}$, però que no es consolida fins als anys setanta, fa que la ciutat deixe de ser vista com un mer contenidor de formes per a passar a ser analitzada com a factor determinant de la vida de les persones i de la comunitat que l'habita.

Com abordar la realitat local urbana, de l'anàlisi de l'espai urbà tal com l'experimenten els habitants, i considerar la realitat canviant i planetària de l'època actual, pot ser un 
repte important de l'antropologia, ja que són les pràctiques socials desenvolupades en els escenaris urbans les que, al capdavall, confereixen sentit a l'urbà.

El treball «Lo que dicen y lo que no dicen las leyes: las palabras en las leyes del suelo y del urbanismo», de M. Dolores Calvet, versa sobre els instruments lingüístics amb els quals s'aborda l'estudi de la realitat urbana. I tracta de fer-ho des de l'àmbit de referència de les lleis i normatives que, al llarg del temps, han incidit en l'entorn i han modelat els territoris i les persones que els habiten.

L'autora, després de fer un estudi quantitatiu de certes paraules en la legislació urbanística dels últims anys, conclou que tant a escala estatal com autonòmica es troben dificultats per a assumir les noves sensibilitats sobre el territori i per a buscar solucions als problemes de la població en general. Les lleis solen presentar un discurs abstracte que, com l'autora denuncia, deixa de banda moltes coses, especialment la realitat de la ciutadania que habita els llocs que les lleis tracten d'ordenar. Però l'autora pretén trobar en la seua anàlisi la veu de qui realment redacta les lleis, les formes concretes de sensibilitat i les intencions respecte a l'ús del sòl.

Per últim, «El lenguaje de las conductas urbanas», de Nora Arias, ens presenta la resposta de la població en un cas de violència urbanística: la intervenció al barri del Raval de Barcelona, intervenció que, segons moltes veus, ha vulnerat drets fonamentals de les persones i que ha estat força discutida des de diversos àmbits. El treball pretén donar veu a tota mena de manifestacions que s'han produït al barri arran de les decisions preses: cartells, dossiers, pel·lícules i eines de debat dels diversos col·lectius, susceptibles de ser repensades, criticades i qüestionades. Una manera de reconeixement dels conflictes, els quals troben en l'ús de la paraula una eina fonamental davant la cultura del control.

Antoni B. Luque Professor de Filosofia 
